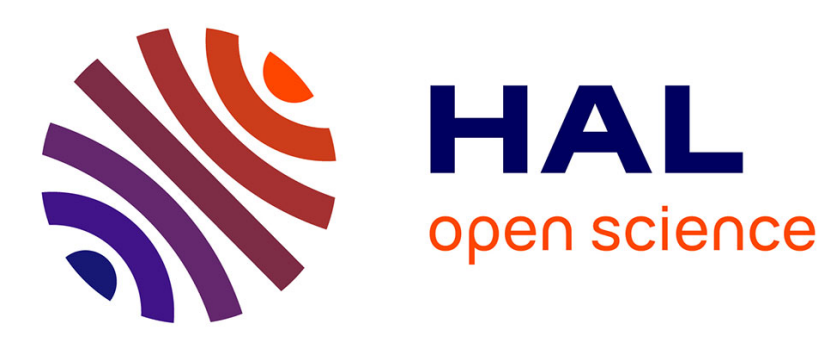

\title{
Urban Nature in the Digital Age. From Collective Urban Gardens to Individual Micro-Landscapes
}

Alessia de Biase, Carolina Marelli, Ornella Zaza

\section{To cite this version:}

Alessia de Biase, Carolina Marelli, Ornella Zaza. Urban Nature in the Digital Age. From Collective Urban Gardens to Individual Micro-Landscapes. Built Environment, 2018, Branded Landscapes in Contemporary Cities, 44 (3), pp.354-373. hal-03469636

\section{HAL Id: hal-03469636 https://hal.science/hal-03469636}

Submitted on 8 Dec 2021

HAL is a multi-disciplinary open access archive for the deposit and dissemination of scientific research documents, whether they are published or not. The documents may come from teaching and research institutions in France or abroad, or from public or private research centers.
L'archive ouverte pluridisciplinaire HAL, est destinée au dépôt et à la diffusion de documents scientifiques de niveau recherche, publiés ou non, émanant des établissements d'enseignement et de recherche français ou étrangers, des laboratoires publics ou privés. 


\title{
Urban Nature in the Digital Age From Collective Urban Gardens to Individual Micro-Landscapes
}

\author{
ALESSIA DE BIASE, CAROLINA MUDAN MARELLI and ORNELLA ZAZA
}

\begin{abstract}
The politicization of urban nature has become almost unavoidable, to the point that the City Council of Paris, like many others European cities, has for a long time been involved in the development of vegetalization's projects in the city. Today the implementation of a corpus of public policies and programmes could be summed up in a desire to achieve great results (100 ha of nature in the city) through devices that are based on small-scale and high participatory value. Beginning with the history of nature in Paris from 1789 to the present day, the article seeks to understand if and how the place given to the inhabitants in relation to the res publica has evolved. The analysis underlines a shift that has taken place in the public policy approach to urban nature, concerning citizen participation in the city's vegetalization projects: the management of nature which was carried out more by collective entities (associations) now seems to be more and more subject to an individual approach (citizen), which has become more widespread thanks to the use of digital platforms and applications.
\end{abstract}

The goal of this research is to understand the evolution of the roles of actors in the management of urban nature in Paris, where the city's council is currently introducing new technologies as part of 'innovative projects'. The hypothesis is that cities, Paris in particular, are implementing two directives that influence the landscape of cities: one concerns increasing the presence of nature in the city, and the other concerns the development of digital technologies. Both these directives are simultaneously cultivated 'top-down' and 'bottom-up'. To increase the amount of biodiversity in the city, the European Union and the French national government are increasingly encouraging the cultivation of various types of vegetation in urban spaces. At the same time, to be involved in what is viewed as an apolitical and consensual fight, city residents are demanding plots on which they can cultivate vegetables. For the second directive, the government and large multinational technology companies are encouraging local actors to develop digital systems to manage the city. Simultaneously, derived from a bottom-up impetus, local actors use, and sometimes produce, new technologies to manage collective spaces (for example, WhatsApp or Slack groups) and most often increase their web presence to support, develop, and communicate their activities.

This study proposes bringing these two directives together to understand, from an urban and anthropological perspective, the roles of varied actors in different historical periods as they negotiate the questions of nature management in Paris. More specifically, the study explores the relationship between nature, technology, and the city from 1789when, during the French Revolution, nature in the city was first de-privatized - to present day Paris. This analysis aims to clarify the 
dynamics between nature, technology, and the city and the way these have influenced design and the players involved or arose as a result.

Why Paris? Current public policies ${ }^{1}$ in Paris provide citizens with incentives to become involved in urban greenery projects, sustained by the introduction of digital tools. In addition, it is important to note that since the nineteenth century, Paris has been using (new) technologies for the management of nature. As an example, under Haussmann, the city was one of the first to experiment with an automatic watering system, which required large changes in the urban infrastructure and the complex relationship between nature, city, and technology.

Spatially, the study focuses on the Parisian city-region, addressing changes in the type of nature (productive nature, nature designed to solve sanitary issues, and nature for leisure purposes), occupations (farmers or gardeners), and techniques (automatic irrigation, pesticides, and fertilizers) that have deeply influenced the structuring of the area.

This study is based on an analysis of archives, historical maps and semi-direct interviews with public policy specialists and officials from the administrative services of Paris Municipality. Through these methods, hundreds of events have been identified and have been ordered in a timeline that explores the relationship between nature, technology, and the city of Paris from 1789 to 2017 . These events were classified into nine categories: social events; labels; urban policies; nature in social housing and public buildings; edible nature; techniques and technologies; public policies, nature as public space; and infrastructure (figure 1). A detailed analysis of these events (taking into account their tensions or connections) demonstrates the evolution of actors in urban greening practices and discourses.

Presenting the evolution of the relationship between nature, technology, and the city, the paper is structured in four parts. The first focuses on the period between 1789 and 1896 when peasants-farmers became citizens and workers, and the status of nature changed. The second focuses on the period between 1940 and 2003, when allotments,

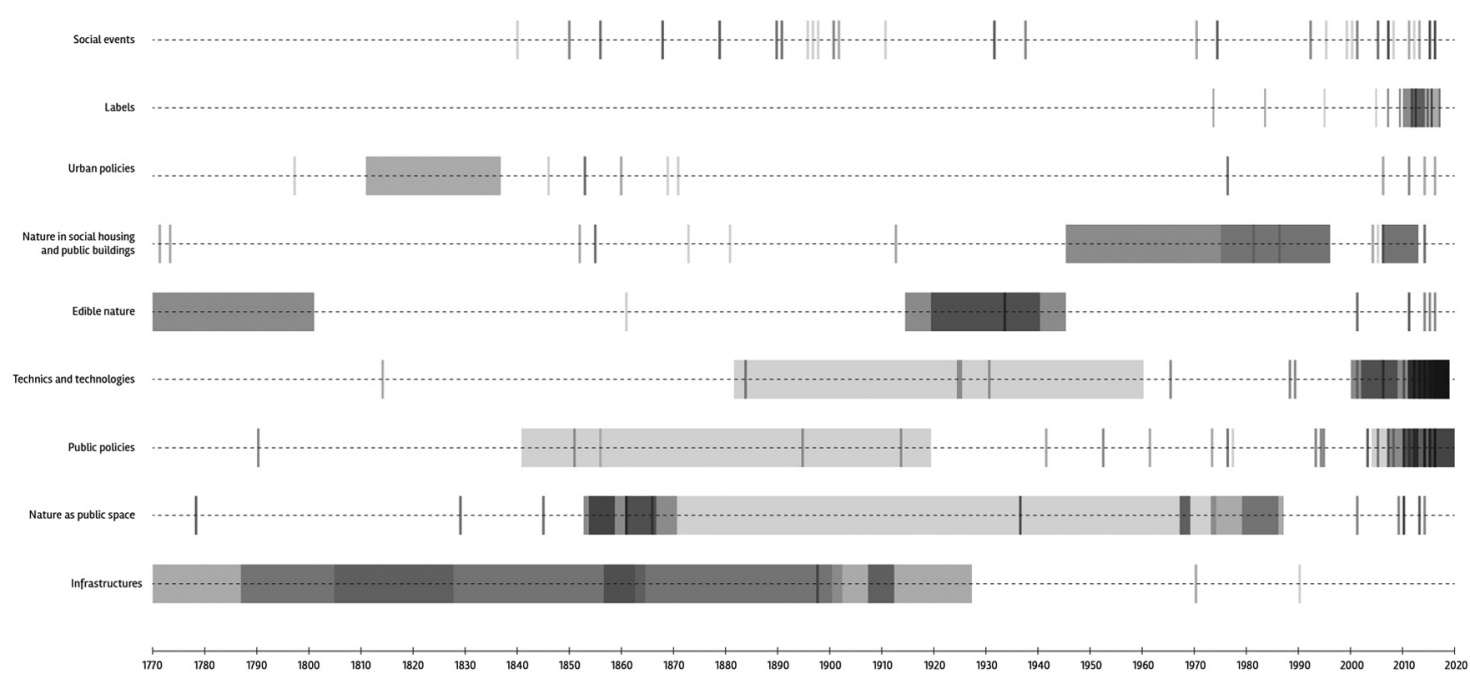

Long period event || One shot event

Figure 1. Paris timeline (1789-2017) about the relationship between nature, technology and the city. (Source: (c) LAA, 2017) 


\begin{tabular}{|c|c|c|c|c|}
\hline & 1789-1896 & 1940-2003 & 2003-2013 & 2013-2018 \\
\hline Natural Spaces & $\begin{array}{l}\text { From farmers' } \\
\text { lands to } \\
\text { labourers' } \\
\text { allotments. }\end{array}$ & $\begin{array}{l}\text { From allotments to } \\
\text { shared gardens. }\end{array}$ & $\begin{array}{l}\text { From shared gardens } \\
\text { to commons as green } \\
\text { spaces. }\end{array}$ & $\begin{array}{l}\text { From commons as } \\
\text { green spaces to } \\
\text { individual micro- } \\
\text { landscapes. }\end{array}$ \\
\hline $\begin{array}{l}\text { Role of Nature } \\
\text { in the Urban } \\
\text { Context }\end{array}$ & $\begin{array}{l}\text { Urban nature is } \\
\text { a fundamental } \\
\text { source of food } \\
\text { production and } \\
\text { subsistence. }\end{array}$ & $\begin{array}{l}\text { Urban nature as leisure } \\
\text { and as something to } \\
\text { protect, share, and } \\
\text { valorize. }\end{array}$ & $\begin{array}{l}\text { Urban nature as res } \\
\text { publica and as a } \\
\text { commons. }\end{array}$ & $\begin{array}{l}\text { Urban nature as an } \\
\text { 'individual project' } \\
\text { through participatory } \\
\text { platforms, mobile } \\
\text { applications, and } \\
\text { micro-sensors. }\end{array}$ \\
\hline $\begin{array}{l}\text { The Main } \\
\text { Actors of Urban } \\
\text { Nature }\end{array}$ & $\begin{array}{l}\text { Peasant-farmers } \\
\text { before and } \\
\text { urban labourer- } \\
\text { farmers after, } \\
\text { grouped in a } \\
\text { unique national } \\
\text { league. }\end{array}$ & $\begin{array}{l}\text { From labourers' } \\
\text { leagues, to families } \\
\text { and civic associations. }\end{array}$ & $\begin{array}{l}\text { Civic associations, } \\
\text { private actors, and } \\
\text { specialized networks } \\
\text { of experts and engaged } \\
\text { people. }\end{array}$ & $\begin{array}{l}\text { Civic associations, } \\
\text { private actors, and } \\
\text { individuals (as a } \\
\text { project leader). }\end{array}$ \\
\hline $\begin{array}{l}\text { Institutional } \\
\text { Responses, } \\
\text { Public Policies } \\
\text { and Local } \\
\text { Regulatory } \\
\text { Systems }\end{array}$ & $\begin{array}{l}\text { Support for the } \\
\text { creation of a } \\
\text { national league, } \\
\text { and the } \\
\text { definition of } \\
\text { public interest } \\
\text { in these new } \\
\text { roles. }\end{array}$ & $\begin{array}{l}\text { The depoliticization of } \\
\text { labourers' garden; } \\
\text { support for the creation } \\
\text { of a national federation; } \\
\text { support for community } \\
\text { gardens; a recognition } \\
\text { role of citizen's } \\
\text { associations; and, a } \\
\text { definition of a formal } \\
\text { and institutional } \\
\text { contract for community } \\
\text { gardens. }\end{array}$ & $\begin{array}{l}\text { Several plans and } \\
\text { international pressures } \\
\text { including the Climate } \\
\text { Plan, the Biodiversity } \\
\text { Plan, the Plan to } \\
\text { Restore and Enhance } \\
\text { Nature in the City, and } \\
\text { the creation of } \\
\text { Observatories and } \\
\text { civic networks (e.g. } \\
\text { Les acteurs du Paris } \\
\text { durable). }\end{array}$ & $\begin{array}{l}\text { Policies of the } \\
\text { ordinary: the } \\
\text { creation of digital } \\
\text { tools and platforms } \\
\text { for co-management } \\
\text { and co-production } \\
\text { processes between } \\
\text { city administrators } \\
\text { and city dwellers. }\end{array}$ \\
\hline
\end{tabular}

family gardens, and shared gardens were born and evolved. The third examines the period between 2003 and 2013, when the role of associations in the management of nature in the city increased; and, finally, the fourth part, analyses the period from 2014 to 2017, and discusses the 'citizen turn' and the emergence of the individual as a new actor in the management of nature in the city. A concluding section emphasizes the main political and social dynamics that have emerged in urban nature and their relationship with new technologies: an urban nature that has become a political and individual instrument, the locus for spectacular events, and a part of urban leisure organizations.

\section{From Peasant-Farmer to Labourer. Towards Institutional Actors: Urban Nature as Public Policy (1789-1896)}

At the end of the eighteenth century, the relationship between nature and the city was largely in terms of food production. At that time, farmers formed the majority of the French workforce (18 million of the workforce), and agriculture was the country's principal industry. Before 1789 (the Old Regime), the social hierarchy was based on the seigneurial system, and only a small percentage of the peasantry owned land.

The French Revolution forever altered this landscape. Although the revolution involved more urban and bourgeois than rural and working-class people, feudal rights were abol- 
ished, and property was 'liberalized' shortly after the revolution. This relation between an urban revolution and agricultural workforce was due to the 'pre-revolution' social and political conditions of millions of people. Just before the revolution, a difficult agricultural season with poor harvests due to frost provoked a rise in the prices of essential products, such as salt and flour. This was complemented by a continuous increase in taxes imposed by the monarchy on 'natural resources' which affected peasants-farmers and city inhabitants.

After the revolution, rural communities, very often structured around the parish, became communes (or municipalities), municipal institutions were established, municipal officials were elected, and some peasants became owners of small parcels of land. Therefore, by the end of the eighteenth century, within the rapidly urbanizing cities, the main actors in the production of nature were peasantfarmers, as opposed to city dwellers. Nevertheless, even with advancing urbanization, the status of the peasant-farmer was only fully recognized in the nineteenth century. The progressive urbanization of Paris pushed farmland and agricultural production further and further away from the city, and retail areas for agricultural products increasingly appeared in the city (including the opening of the Marché des Halles in the centre of Paris in 1852). Plants were also increasingly being recognized for their medicinal properties (with the first experiments at the Salpêtrière Hospital, and then in Lariboisière) and as a source of leisure (leading to the creation of the Bois de Boulogne in 1853, for example) (figure 2).

Meanwhile, the first industrial revolution

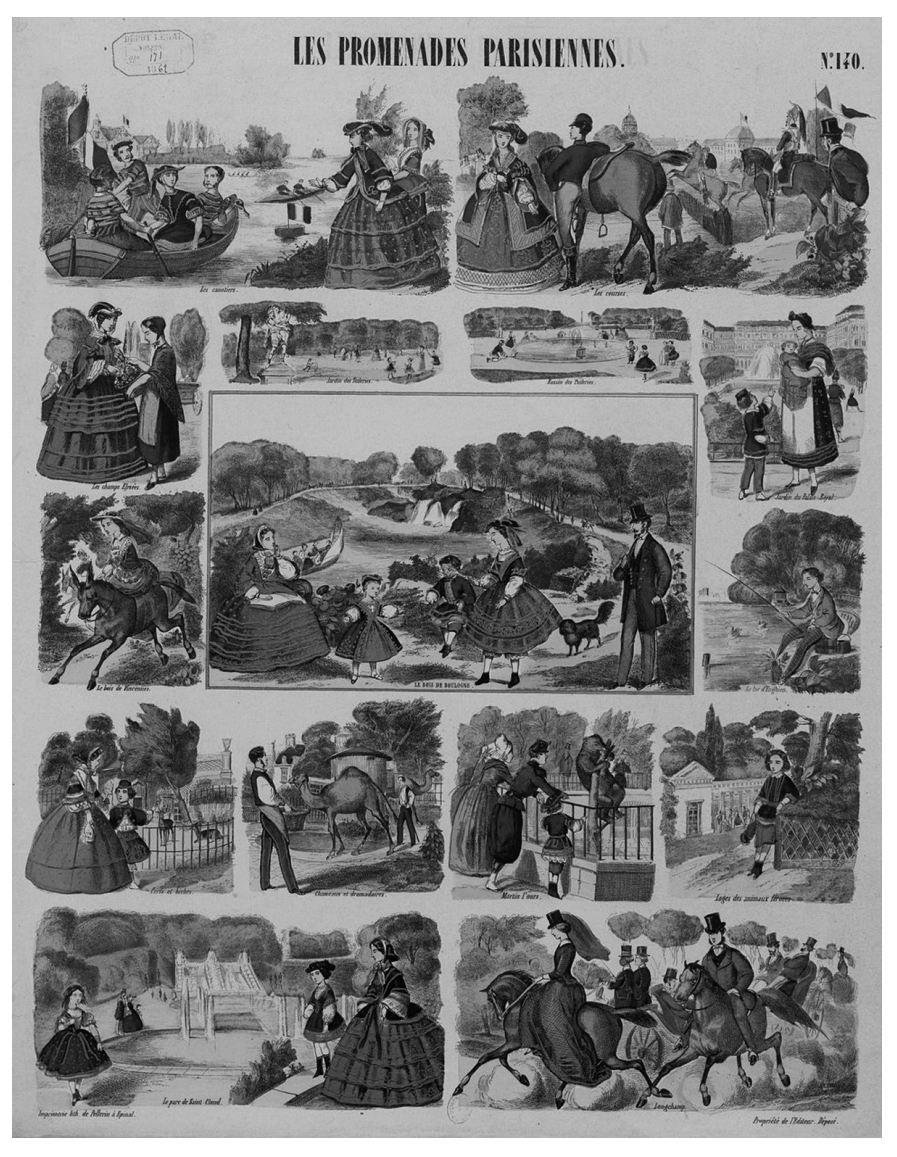

320
Figure 2. In this illustration of 1869 , Parisian parks and woods were tale as 'public spaces' for leisure activities of upper social class. Title: Les promenades parisiennes. Jardin des Tuileries - Bassin des Tuileries - Les Champs Elysées - Jardin $d u$ Palais Royal - Le bois de Vincennes Le bois de Boulogne - Le lac d'Enghien - Le parc de Saint Cloud - Longchamp. $N^{\circ} 140$. (C) Pellerin, 1869. Editor: Imagerie Pellerin. Technic: Colour woodcut, $47 \times 37 \mathrm{~cm}$. (Source: gallica. bnf.fr / French National Library - BNF / https://catalogue.bnf.fr/ark:/12148/ cb413739761) 
began to affect Paris, and it became the destination of choice for millions of ex-farmers, creating a large working-class population. At the same time, this urban turn was strongly influenced by the farmers' background. Thus was born a phenomenon that would become familiar on the outskirts of all northern European cities: the allotment (Bartoletti, 2012). These areas quickly spread throughout Paris and the rest of France, often occupying unused spaces on ex-military sites which no longer functioned as enemy deterrents (such as forts or within 'Thiers city walls').

Alongside peasant-farmers, labourers adopted a new role in the city as actors in the production of nature. Although the primary goal of this type of urban nature was sub- sistence food production and the improvement of public health (Dubost and Lizet, 2003), with time, it took the form of a political and collective demand from the working and proletarian classes. A movement led by Abbot Lemire established in 1896, grew and organized itself into the French League for a Piece of Land and the Household (Ligue Française $d u$ Coin de Terre et $d u$ Foyer). Although its main objective was to provide the head of each household with a piece of land in order to grow vegetables that the family could eat, the League played a significant role in uniting the proletarian class and recognizing its demands (figure 3). Born of the acts of philanthropists (mainly from the Catholic Church), La Ligue Française du Coin de Terre

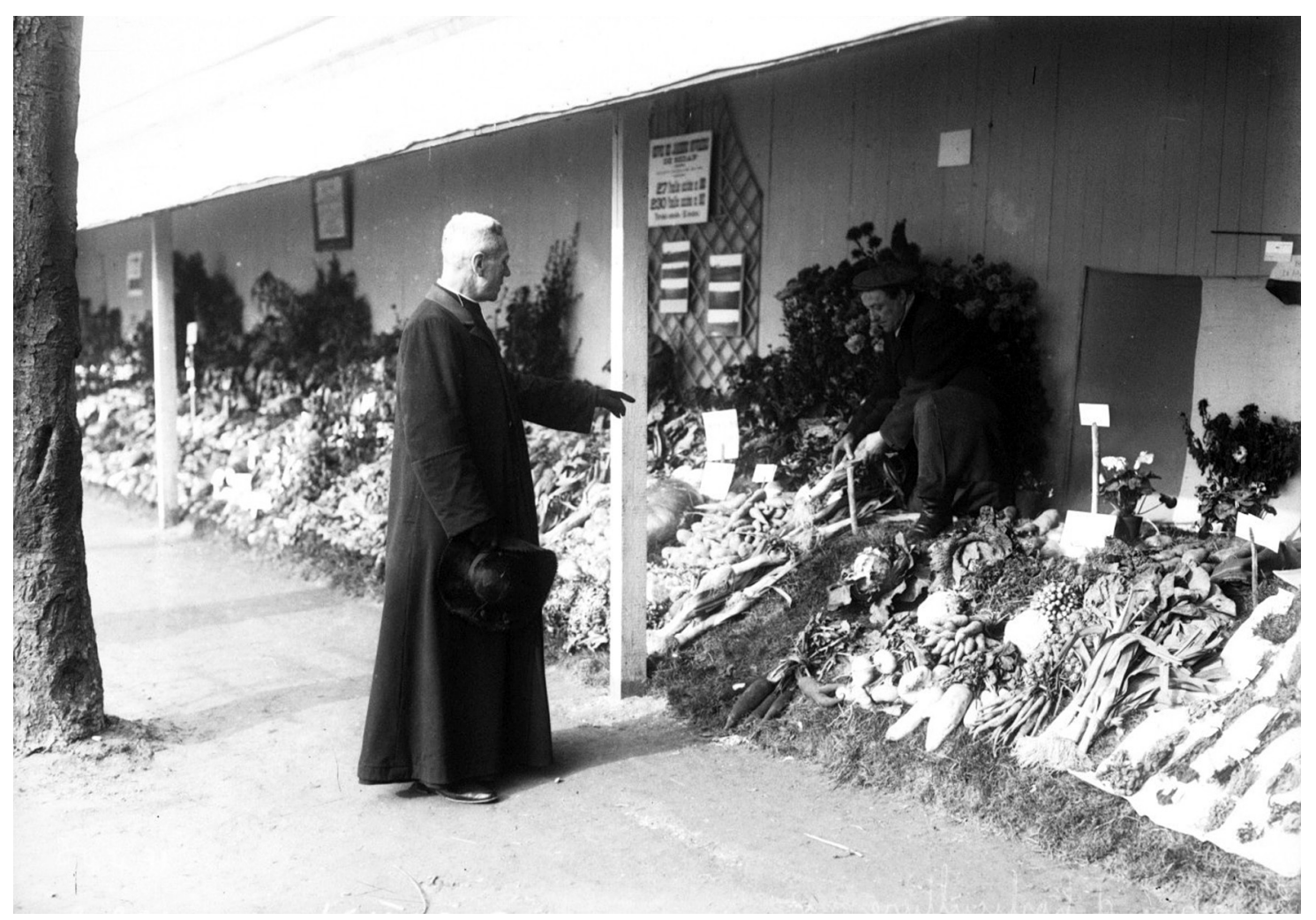

Figure 3. Abbot Lemire at the Horticultural salon in Paris. He was one of the central figures (at the national and the Parisian level) for the emergence of collective actors, claiming for the recognition of nature as means of survival for proletarian class in urban contexts. Title: [8-11-12] exposition d'horticulture [au Cours la Reine à Paris, abbé Lemire]. (c) Agence Rol, 1912. Technic: Photography on glass, 13x18 cm. (Source: gallica.bnf.fr / French National Library - BNF / https://catalogue.bnf.fr/ ark:/12148/cb40462373x) 
et $d u$ Foyer was the first organization to be recognized as a proponent of the social necessity of urban nature. It was the first collective and institutional actor with private participation in urban nature (as it brought together groups of individuals), but it was recognized as being of public interest, and the government itself gave the organization several grants and roles.

\section{Allotments, Family Gardens and Shared Gardens: Nature in the City Fostered by Local Associations (1940-2003)}

Between 1940 and 2003, three main periods marked the significant transformation of the role of nature, its relation to the city of Paris, and the actors involved in its governance. First, from 1940 to 1944, when nature was conceived as a possible vassal of the Vichy government's political values; second, from 1950 to 1970, during the Cold War, when there was a depoliticization of the link between communist ideologies and urban nature allotments (labourers and industrial gardens); and third, from 1970 to 2003, when civic associa-

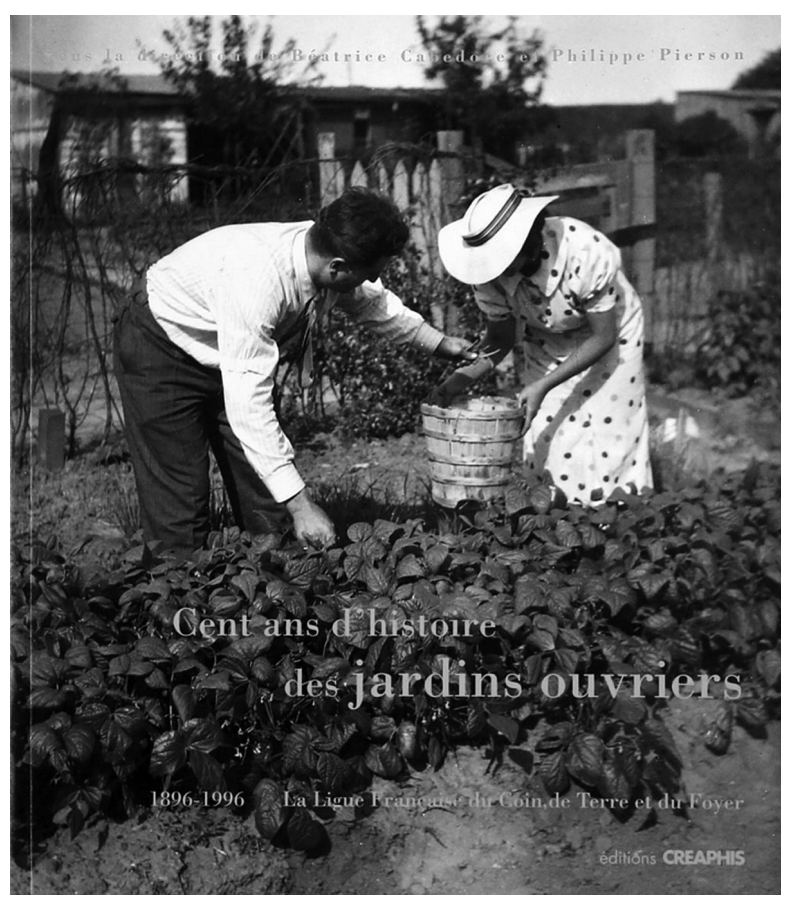

tion and informal groups of inhabitants appeared as new actors in the production of urban nature, engendering a new political imagination for these spaces.

During the Vichy government (1940-1944), political leaders viewed productive gardens as a means of supporting a return to family and land values in urban contexts (Guyon, 2008). This was in line with the National Revolution of the Vichy government, a celebration to return to agriculture; as a possible way to lead to an individual and national renewal and the proximity to the land was supposed to produce healthier minds and bodies, far from the vices of the city (Pearson, 2012).

However, after the war and during the first period of the Cold War (1945-1970), renewed institutional interest saw investment in the productivity of natural spaces. A form of 'depoliticization's of these productive spaces took place: allotments (in French: jardins ouvriers, which translates as 'labourers' gardens') were renamed 'family gardens', thus removing the reference to the working class in favour of social and familial criteria (figure 4). This was the Federation period, and the unique actors
Figure 4. Cover of the book Cent ans d'histoire des jardins ouvriers, 1896-1996 by Béatrice Cabedoce and Philippe Pierson (Paris: Éditions Créaphis, 1996) showing a family making its own garden. 
recognized and supported by public policies in the vegetalization of urban spaces were 'federative'. The Federation of Jardins des Cheminots, the Fédération Nationale des Jardins familiaux, and the Société Nationale d'Horticulture de France are examples of the most representative federations of jardins familiaux born during this period.

Meanwhile, the economic recovery and access to a wider mass production of food would subsequently modify the essence of these gardens, and the use of family gardens for food and livelihoods, already in decline, continued to diminish in importance. In 1945 , at the end of the war, there were 700,000 family gardens, but this number began to decline in the 1950s.

In the 1960s, a leisure role was slowly attached to these gardens, and they were gradually established in low-income housing developments. The belief behind this, still held by modern movements, was that nature could have a restorative effect, stimulating peace, beauty, and social harmony (Dubost and Lizet, 2003). Green open spaces, being neither private nor public, are considered common spaces that are conducive to the community spirit (ibid.). Within low-income housing lots, family gardens gradually became a form of nature used as a basis for leisure.

Although they underwent several functional and typological restructurings over time (from 'labourer' to 'family' and from subsistence production to nature as leisure), the actors with influence on nature in French cities remain linked either to the sphere of public authorities (controlled and financed by either City Hall or the state), or to large private groups for public benefit (such as low-income housing landlords).

However, in the late 1970s, another change took place. The processes of urbanization and de-industrialization led to the emergence of new residual and unexploited spaces, first in the United States and then in Europe, that would be the subject of a new discourse and new practices of nature in cities. These were brownfield sites, abandoned businesses, and small gaps in the urban sprawl, which could be given new value with the addition of urban nature. In the 1970s, a group of friends who called themselves the Peace Corps, the so-called members of the post 'flower-power' generation (Pasquali et al., 2008), established the first non-profit 'guerrilla-gardening ${ }^{\prime 3}$ actions. Although community gardens were continually popping up with the short-lived experiments of 'guerrilla-gardening', they gradually became more lasting, and new ideas emerged. ${ }^{4}$ Whereas guerrilla-gardening introduced urban nature to a particular space but did not continue to manage these spaces, the new idea was to create something more permanent, which would be available to all city dwellers.

In France, thanks to community leaders, militant peasant-farmers, and gardeners, similar experiments pervaded throughout the end of the 1980s. Mirroring the community garden experiments in the United States, les jardins partagés began to appear. At the beginning of the 1990s, they spread throughout the Paris region, where initiatives lead by neighbourhood, or residents' organizations first appeared in the east of the city. They subsequently spread throughout Paris, especially in brownfield sites. ${ }^{5}$ The appearance of community gardens thus has its own history, a history that shares only certain practices with those of allotments (jardins ouvriers) first, and then family gardens (jardins familiaux) afterwards. Current experiments, which are increasingly oriented towards the concepts of 'sharing', 'well-being', and 'back to nature' - as devices for sociability where cultivating and producing food is no longer the final goal - are not congruent with the garden experiments of labourers that were based on a real need for food subsistence (Bergamaschi, 2012). This is true even though certain principles, such as leisure and environmental protection, can be traced back to family garden experiments. ${ }^{6}$ In the face of these emerging phenomena, interest from territorial authorities became increasingly strong, albeit continually fluctuating. This has led to multiple different typologies, each with a 'collective' character. 
Alongside 'shared' gardens, gardens labelled 'associative' or 'solidary', and gardens set up for employment and training have emerged (Fortier, 2003).

In Paris, the local public institutions, not knowing what position to take with the diversity of management types, practices, typologies, and aesthetics of these rapidly growing initiatives, have gradually tried to regulate their time-span and location (as the initiatives were often established in abandoned or transitional spaces, which therefore represent exploitable land in the eyes of the public actor). Consequently, shared gardens started to become more 'standardized' (Uttaro, 2012) in terms of the management methods of occupied spaces: exclusively, the actors involved began to be only organizations; the spaces became delimited with a fence with openings provided for the public; and, the projects' time-span was defined by a temporary occupation contract (Convention d'occu-

\section{MAIRIE DE PARIS}

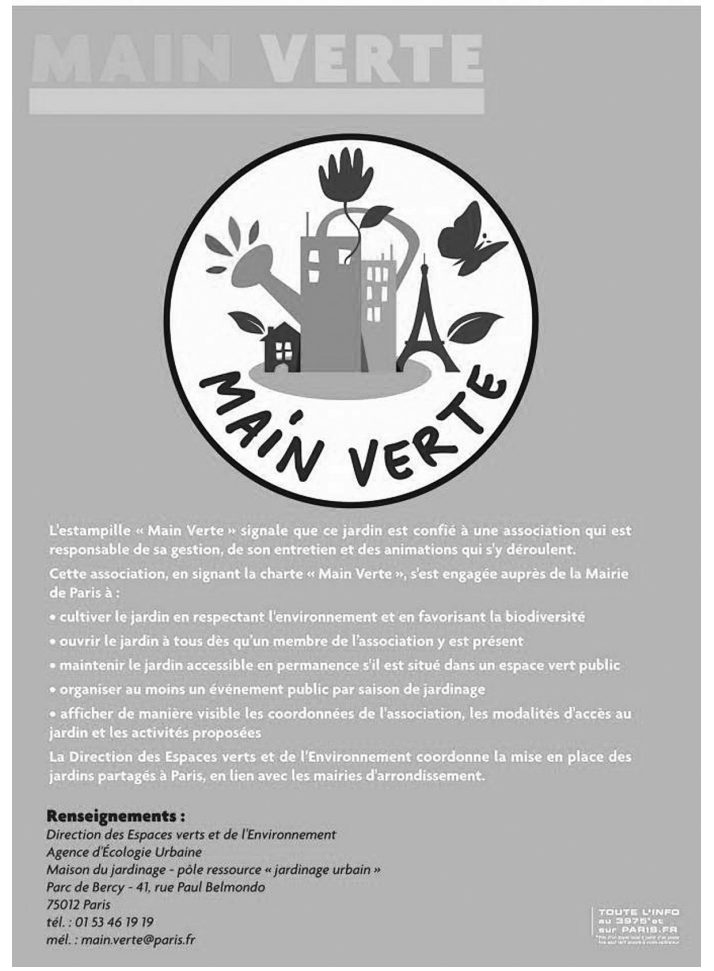

pation temporaire $d u$ sol, COT) which, while renewable, prevents any possibility of planning permanent initiatives in the face of projects defined as 'priorities'. Due to this conferred temporary status and a reaction to pollution or a lack of cultivatable soil, shared gardens appeared that were increasingly 'mobile', including aboveground plantations. In Paris, the Charte Main Verte, signed by the organizations that occupied plots in 2003, articulates their principles and commitments. According to this charter, organizations must follow four principles: they must guarantee participatory procedures, remain open to the public, create social connections, and respect the environment. Alongside these, the organization is held to a series of commitments: the garden must stay open to the public with one of the association's members present for at least two half-days per week (including preferably one during the weekend); the organization must organize at least one event per gardening season; the organization must clearly display their contact details, the rules for accessing the garden, and the activities offered; and, finally the organization must commit to the ecological management of the site (no phytosanitary products are allowed, and particular waste management is demanded).

Figure 5. Poster explaining the rules of Parisian shared gardens and who carries them out. The text reads: "The stamp "Green Hand" indicates that this garden is given to an association which is responsible for its management, maintenance and events that take place there. By signing the charter 'Green Hand', this association is committed to the City of Paris to: cultivate the garden by respecting the environment and promoting biodiversity, open the garden to all as soon as a member of the association is present, keep the garden permanently accessible if it is located in a public green space, organize at least one public event each gardening season, display in a visible way the coordinates of the association, the access modalities to the garden and the events agenda. The Green Spaces Directorate [of Paris City Hall] coordinates the implementation of shared gardens in Paris, in conjunction with the local districts'. 
Thus, with the appearance of shared gardens, the actors who took over the production of urban nature were increasingly residents or volunteers (often comprising local organizations). While participation in nature was mainly relegated to categories of specific actors managing specific spaces (parks and botanical gardens by the bourgeoisie, allotments by the working-class, and the countryside by the peasantry), nature increasingly concerned all city dwellers (figure 5).

\section{Nature as 'Res Publica': Between 'All City Dwellers' and Economic Actors (2003-2013)}

The associative character and the unifying spirit that characterized the development of urban nature is a testament to the progressive perception of urban nature as 'something for everyone', and a 'common good' to be cultivated. In fact, it is especially through the triumph of the sustainable development paradigm that the trend to treat urban nature as res publica was reinforced. Widely popularized after the 1992 Rio de Janeiro summit, sustainable development has since continued to occupy the political and media arena. Under the guise of sustainable development, 'urbaphobia's reappeared, wherein nature is called upon to almost 'de-urbanize' the city: to fight against urban heat islands, to contribute towards urban resilience, to satisfy citizens' food requirements, and to create a calmer and more breathable environment.

Within this context, large companies, real estate developers, and startups have taken their place in the political project of sustainable development, but in potentially ambivalent ways. Although they have strongly contributed to the environmental crisis (due to pollution and industrial exploitation), they present themselves as essential actors for the proposition of new solutions in the sustainable development domain (especially concerning the development of new technologies) (Aggeri and Gordard, 2006). By adopting 'eco-responsible' or 'sustainable' behaviour (dating back to the 1920 in the United States, and a short time later in Europe), they have participated in the debate about nature as a 'public affair'. Through their products, they have rendered nature an economic activity like any other (Hervieu and Viard, 1997), bringing these actors into the arena of production of urban nature, and they have truly created an economic field that is specific to the environment (Bourdieu, 1997) (as opposed to the way the Leagues did before).

In terms of the 'production of laws' (Latour, 2002), the trend of treating nature as res publica became more explicit. This is in contrast to the end of the eighteenth century, where urban nature was supported mainly by leagues or companies or was focused on specific schemes and one-off interventions. ${ }^{9}$ Gradually urban nature has been recognized, and it has taken up a place in its own right in its relationship with urban space. After the appearance of the concept of 'green space' (1961), texts were steadily drafted on this topic that include, among others, the Memorandum on Urban Green Spaces (Circulaire Espaces Verts Urbains, 1973), the Law on the Protection of Nature (Loi relative à la protection de la nature, 1976), the Convention on Biological Diversity (Convention sur la diversité biologique, 1992), and the Bonn Call for Action (2008).

This process has been supported by the injunction of sustainable development, which has become more of an urban issue than an exclusive state issue. In Paris, this became eminently visible during Bertrand Delanoë's two terms as Mayor of Paris (2003-2008, 20082014) ${ }^{10}$ and was strengthened by the next mayor, Anne Hidalgo (2014-2020). Several plans have been written that account for the centrality of nature: the Climate Plan (Plan Climat, 2004), the Biodiversity Plan (Plan de la Biodiversité, 2010), and the Plan to Restore and Enhance Nature in the City (Plan Restaurer et valoriser la nature en ville, 2010). Alongside this, observatories are proliferating, including the Parisian Biodiversity Observatory, or the Observatory of Green Cities, which aim to observe the current phenomena, and to 
monitor actions. In sometimes contradictory ways, they may function as supervision, but also as criticism. The Paris COP21 in 2015 was also a strong political sign of movement in this direction. A worldwide network of cities (C40), overseen by Paris City Hall, signed a charter stipulating several local urban measures against climate change. Amongst these, an increasing presence of urban nature, a process that increasingly goes by the name of 'greening', became a key element, which gained growing support from a series of specific public policies. In this way, initiatives that favour urban nature are in 'project mode', helping to transform the discourse surrounding the practice of greening. The majority of 'innovative' institutional initiatives $^{11}$ promote, for example, urban agriculture; while others that do not claim to be 'innovative' promote the implementation of urban projects that denote a central role to nature in all its forms (Label Ecojardin, 2012; Label Ecoquartier, 2013).

Overall, the initiatives of public actors strengthen the idea that nature may be for 'all' and attempt to bring actors together towards a 'common' goal, the proliferation of nature in the city. These include, for the most part, calls for projects or events and in Paris, including the call for 'Innovative Greening' ${ }^{12}$ (Végétalisation innovante, 2013), the meetup ${ }^{13}$ events 'Let's Green Paris' (Végétalisons Paris, 2016), and the 'Parisfarmers' ${ }^{14}$ (Parisculteurs 2016 and 2017). The Innovative Greening AMI was the first initiative launched by Paris City Hall to unite the different actors and to create a network, even before the action of producing urban nature. The goal of the local public actors was to unite longstanding green actors (including gardeners and organizations) with the new emerging greening actors (such as the startups offering new technological solutions for watering and sensors for monitoring plants).

This intensity in the production of normative frameworks and public procurement for growing nature in the city demonstrates that the vision of nature as res publica remains, nevertheless, very structured. The commitment provided for in the Charte Main Verte demonstrates this: a 'rightful owner' is defined, the freely accessible spaces are closed, and the management of collective gardens is submitted to a contractual form. Non-profit organizations dedicated to the reintegration of nature in the city began to appear, while public actors increasingly took up the role of vigilant 'coordinators' and sought to regulate the location, functioning, and proliferation of these projects within the city.

This tension between sustainable development and nature as res publica led progressively to the emergence of two main contemporary actors in the production of urban nature: citizens and businesses.

With businesses, it is possible to identify those whose goal it is to produce and sell plant food products grown in the city, while focusing on short distribution channels, as opposed to the more classic industrial or agricultural food channels (like the mushroom producers of Paris, established by a small business in an SNCF train tunnel in Paris in 2011). There are businesses that promote themselves as project developers or as managers of new natural spaces (the best known in Paris is the company Topager) (figure 6).

There are also businesses that mobilize nature as a setting and an element for leisure to be consumed while carrying out an economic activity. The model of this in Paris is the Récyclerie ${ }^{15}$ (2015) in Porte de Clignancourt, in the northeast of the city. This type of business (often of small size) usually enhances abandoned and precarious land (as community gardens do indirectly), using nature as a structural element in their marketing strategies. People choose these sites because of the 'sustainable' setting they offer, the short distribution chains that they trigger, and sometimes because of the social welcome or educational opportunities they provide (Soulard and Thareau, 2009). In short, their economic needs are met by nature projects, which make them 'more of a winner' than other consumer spaces. 


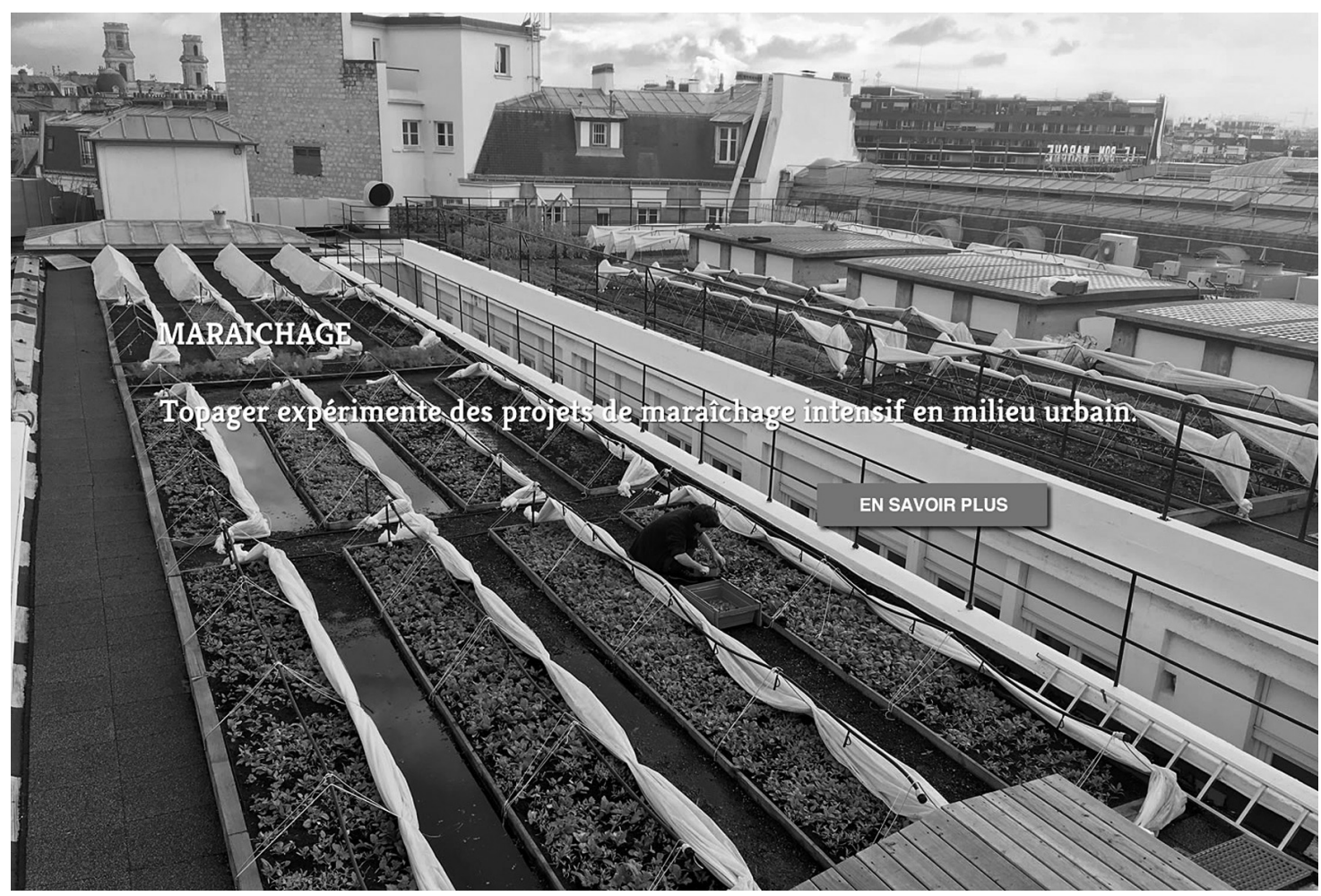

Figure 6. A Topager advertisement for gardening services it offers in urban contexts. (Source: (C) Topager, 2018. http://topager.com/)

Finally, there are many different types of new, self-proclaimed innovative companies producing new solutions (from digital technologies to unusual growing methods). These include companies which propose new growing materials and techniques, develop technologies for the management and monitoring of plants, and design digital tools for networking actors involved in the production of urban nature (figure 7). Within this context, the more 'classic' professions linked to the production of urban nature evolve. The required composition of teams for innovative urban projects promoted by Paris City Hall since 2014 demonstrates that gradually knowledge linked to nature has appeared among the skills required. These are not landscaping skills (as may have been required previously), but instead, knowledge linked to urban agriculture. Consequently, they are called 'urban peasant-farmers' or 'city farmers', terms that place equal emphasis on the place in which the profession is practiced and the inherent challenges of the role (which go beyond production). The profession of agriculture has become an object of negotiation in a primarily urban arena, and its role has evolved from technician/producer to include mediator/facilitator/holder of nature (Poulot, 2014). By inviting the 'actors of nature' to propose new techniques for greening Paris, these expressions 'urbanize' and risk caricaturing the profession of the farmer.

The public authorities' stated aim, and part of the promotion of nature as a res publica and as the main factor for sustainable development, was to maintain Parisians' 'quality of life'. Nature became an object in its own right, and the goal became to preserve it or strengthen it in the city, without referring to a particular community or social class. In other words, these efforts highlighted urban 


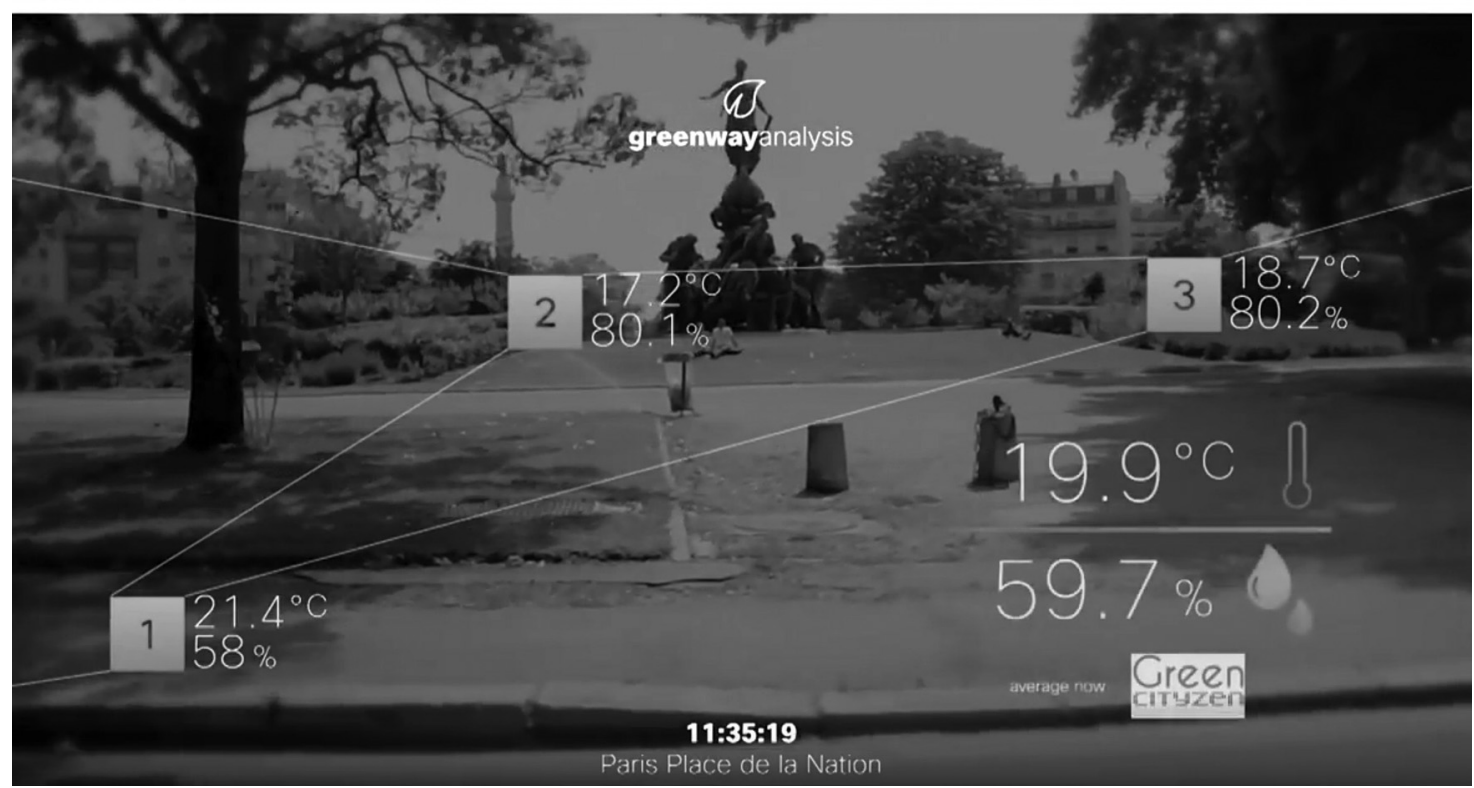

Figure 7. The Green CityZEN enterprise has recently experimented with digital sensors to monitor soil moisture, soil temperature, rainfall and wind speed of public green spaces, in order to adjust watering routines at Place de la Nation in Paris. (Source: (C) Green CityZen, 2017. https://www.youtube.com/ watch?v=rlXsY9h7eyw)

nature as a general good created for the city community (or national or global communities). There is no spirit of social protest, but instead, one of shared responsibility, from government actors down to the citizens, in a highly mediated manner.

Thus, urban agriculture projects in public spaces that are 'open to all' were initiated. One example is Incroyables Comestibles, a movement that emerged in 2008 based on its English homonym, 'Incredible Edibles'. This citizen participatory movement aims to achieve regional food self-sufficiency and healthy, shared food for all. Intermittent actions scattered throughout Paris by collectives claim to be supporting an autonomous productive nature in the city: in this way urban agriculture has regained an economic and environmental role (Poulot, 2014) and has also become a site for the promotion of sociability and solidarity (Rieutort, 2009).

Thus, nature reunites public actors, private actors, and citizens through a shared pragmatist approach and vision.

\section{Towards Digital Practices of Urban Nature: The 'Citizens' Turning Point' (2014-2018)}

In his book The Metropolis of Individuals ( $\mathrm{La}$ métropole des individus), Alain Bourdin said, 'The 2oth century was very much about action' (2005, p. 153) and he identified pragmatism as the structuring thought of the last three centuries. Through Frederick Winslow Taylor and Herbert Simon, Bourdin recognizes rational action as the paradigm of society since the industrial revolution. To confirm this, he evokes the management sciences that today increasingly assert themselves, as they analyse the more artifactual shape of collective action' (Hatchuel quoted in Bourdin, 2005, p. 154). In light of this, an evergrowing part of urban studies affirm that the city is also affected by similar productive 
mechanisms (Lefebvre, 1974; Harvey, 1985; Monnier and Klein, 2002; Biau and Tapie, 2009), of which the urban project is one of its best expressions (Ingallina, 2001). Some have pushed this reasoning back to the trend of viewing human existence itself as a project (Boutinet, 1990); in what Foucault would have probably called 'the project of the self'. In this process, the figure of the individual is placed in the centre. Meanwhile, in the 'City project' of Boltanski and Chiapello (1999), the human being is sure of himself, inserted into a complex network of actors and resources, and as he is 'great' (ibid., p. 163), he is recognized through his 'activity' (ibid., p. 165). He is a citizen, but he is seen as an 'individual project leader'.

In this context, the use of new digital technologies affects the way we can see, manage, and think about urban nature. Participatory platforms, mobile applications, and microsensors have gradually been integrated into public action for sustainable development. If these new technologies had an easy application in the energy field (monitoring consumption, for example), they were more likely to be introduced in the field of urban greening. Originally used primarily by public services, new digital interfaces allow more interaction ('web 2.0', and more recently, 'web 3.0') and lead to co-management and co-production processes between city-administrators and city dwellers. Gradually, the logic underlying electronic participation more often involves the principle of action, rather than debate, whether it is societal or political. Thus, the discourse on urban nature as a 'public affair' and a key factor for sustainable development contributes to the introduction of new businesses (as experts, owners of land, and funders) into urban greening process, and calls on citizens to 'act directly' in greening their living environment (the city). This second phenomenon, which is identified as the 'citizen turn', seems to dominate contemporary public policies about urban nature and is increasingly reinforced by the use of new digital technologies.
In Paris, the bases of public trees, with their grates on Parisian pavements, and their evolution in terms of management, discourse, and practices is very telling. The iron grates at the base of trees, designed by Alphand during the Haussmann period, posed management problems (Pellegrini, 2012) mainly due to their cost and the number of City Hall directorates required for their daily upkeep (Directorate of Roads and Travel, Directorates for Green Spaces, and Directorate for Water Cleanliness). In 2009, a lawsuit brought by the National Union of Disabled People (Union Nationale de Moins Valides, UNMV) against the city of Paris, made these grates illegal due to the risks they posed to people in wheelchairs. In addition, since 1 January 2017, Paris City Hall has stopped using pesticides in public green spaces, and the bases of these trees quickly became a weed control problem under the grates. New methods of protecting the base of trees were therefore needed. This led to an enlargement 'of the protection array for the bases of trees' (Bracciano, 1995) and the use of a porous 'stabilized' material (Pellegrini, 2012, p. 7). Within this enlargement to the forms of protection, the City Hall has proposed new green practices from 2015: Permis de Végétaliser (Permit to Green). Paris City Hall provides permits to 'green' a small lot, the base of a tree, or the corner of a road to city dwellers who request them. Once the permit is obtained, a three-year occupancy agreement is signed with certain obligations (no pesticides are permitted, and a list of recommended species, as melliferous plants, is provided), and a plantation kit (one with tools, the other with earth, seeds, and bulbs) is offered to those who desire it. From this point, the base of trees become a matter for the individual city dweller, and the territorial authority absolves itself of the maintenance work. The individual city dweller 'takes responsibility' for nature and in return is offered the necessary materials (figure 8).

This phenomenon of individualization and action on the urban environment by the individual city dweller through nature is made 


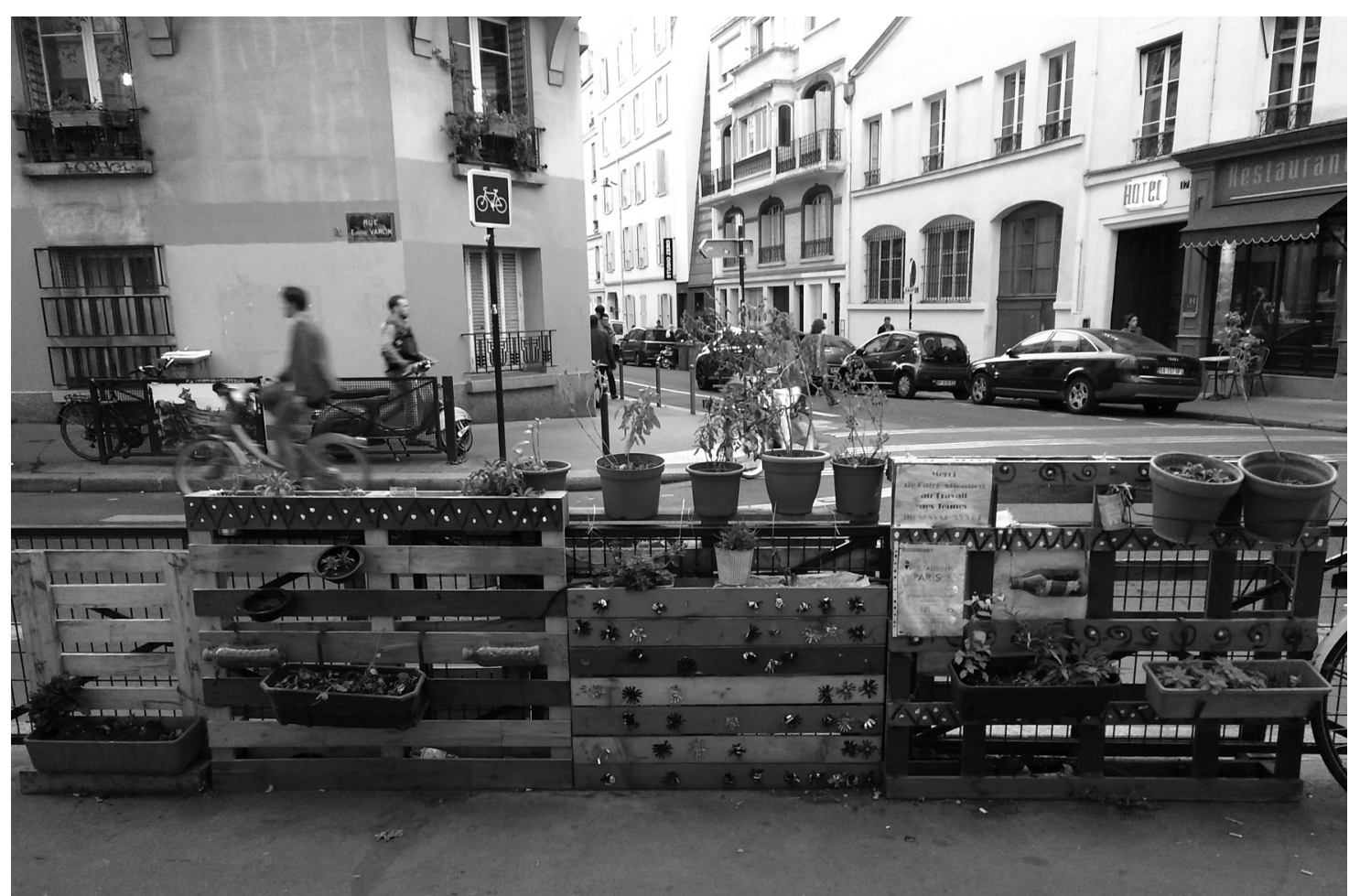

Figure 8. A Permit to Green managed by a citizen in Paris, October 2017. (Source: (C LAA, 2017)

even more visible by the introduction of digital tools for city management, thus reinforcing the myth of 'the individual project leader'. Although the first digital tools developed by public authorities concerned municipal services (at the beginning of the 2000s, Paris City Hall set up sensors in the trees and provided public officials with tablets for plant maintenance), a host of other digital tools impel the city dweller to take an active role in City Hall's political project of greening. Now a 'project leader', they can self-train and selfinform through digital platforms, ${ }^{16}$ showcase their project, promote it, and unite as many people as possible around it. ${ }^{17}$ Whereas the emergence of new techniques and technologies in the past was mainly linked to production and management issues since the 2000s, their use has also been particularly linked to educational concerns and to publicizing the greening process.

This is no coincidence, as in Paris, the notion of citizen intervention in the 'urban fabric' is also present in the discourse surrounding the 'smart city'. The individual city dweller can take a central role within city projects, as much as organizations or companies. Through digital technology, they can participate as an individual in the public debate and take part in the creation of new urban green spaces. The consultation for the Biodiversity Plan in 2016 is a good example of the use of new digital technologies because the public debate for this plan was also carried out on a 'participatory' digital platform. For participating in the creation of urban green spaces, which seems to be put forward increasingly in contemporary public policies, the Some Green Near to My Home (Du Vert près de Chez Moi) initiative demonstrates how citizens are 'called to action' by public authorities. Launched in 2014, this initiative allows citizens to propose new urban spaces to green to Paris City Hall. Citizens' 
suggestions are made individually by smartphone, through a mobile app that sends GPS information on the suggested space to the Paris City Hall's municipal services. Moreover, the most recent digital platform, Let's Green Paris (Végétalisons Paris) developed and inaugurated by Paris City Hall in 2017, is a good example that demonstrates the extension of this logic. Citizens who wish to participate are invited to make an audit of nature in their private space, to be placed in a 'common urban basket', with the aim of reaching 100 hectares of urban nature (the political objective that Paris City Hall propose to attain by 2020). By participating in the auditing of urban nature, citizens 'pool' their domestic space, and can network with other citizens to help co-manage a 'piece' of nature in the public space and they do this because they are responsible citizens (figure 9).

As Nathalie Blanc (2013) points out, two different positions exist in the relationship between the individual and nature. The first would consider nature as a separate entity, which has nothing to do with human beings. Self-sufficient, its destiny is distant and parallel to that of the individual. This type of positioning would lead to the abandonment of all moral concepts in favour of rational logic and utilitarian calculation. In contrast, the second, which this study is more focused on, would be built around moralism and the feeling of guilt: the individual feels guilty for climate and environmental disturbances, and is thus compelled to act considerately both towards their proximate environment and towards their more distant environment (of the entire planet and future generations). These contemporary ethics of 'care' (Gilligan, 1982; Tronto, 1993) have compelled individuals since the 1980 os towards taking responsibility for caring for the earth and, consequently,

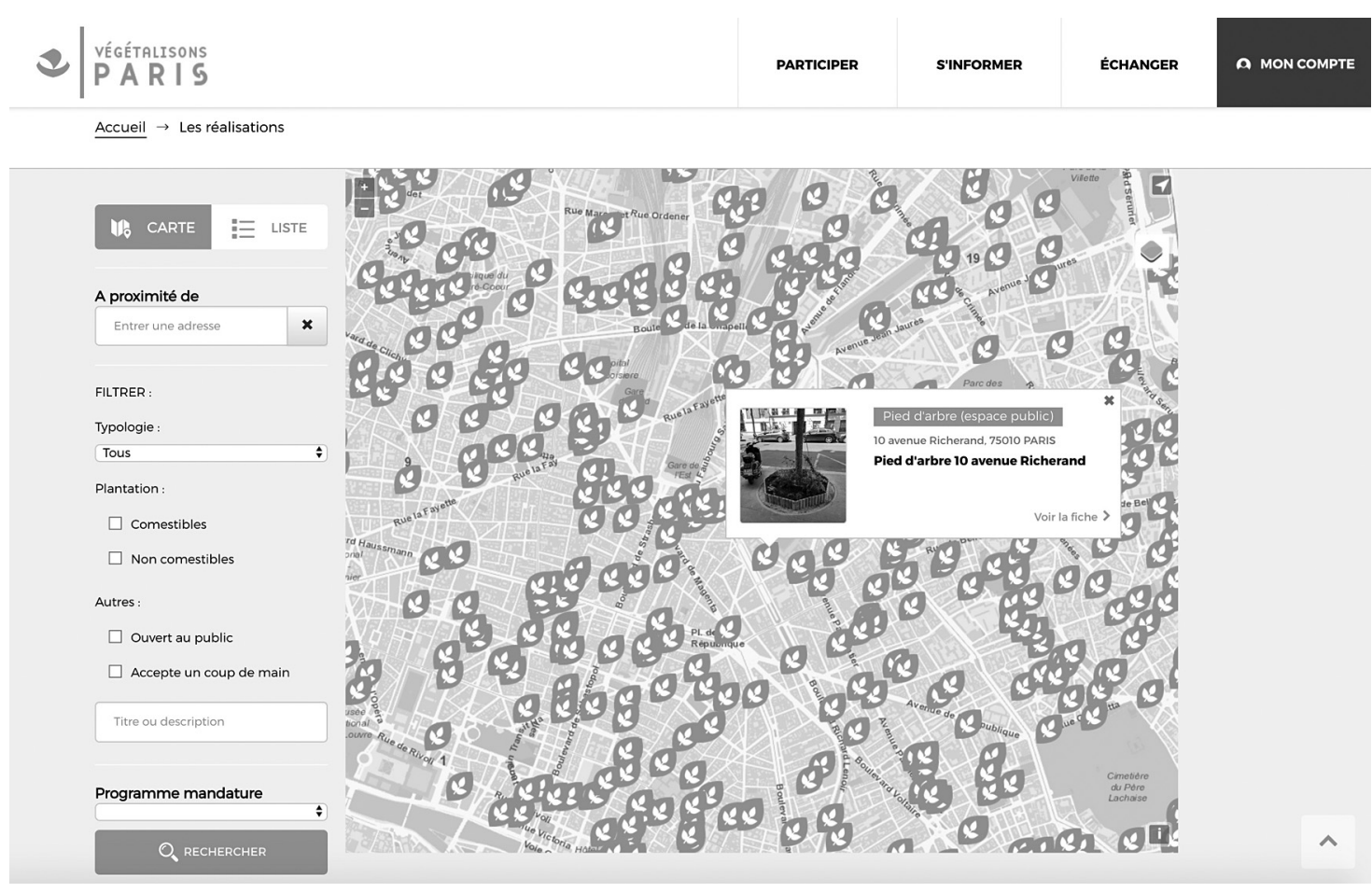

Figure 9. Screenshot of the digital platform Let's Green Paris, showing the collaborative map where citizens are called to inventory their 'green projects'. (Source: https://vegetalisons.paris.fr/vegetalisons/jsp/ site/Portal.jsp?page=project\&view=searchProjects) 
ethics are performing as a 'policy of the ordinary' (Laugier, 2009). Responsibility in the face of res publica is based more on the moralizing of the life of the individual city dweller, while the public authority takes up the role of a benefactor, granting spaces to city dwellers for their actions. It is 'good' if each citizen also takes care of 'public nature' and is engaged in the protection of the environment and the creation of a more sustainable city.

It is at the intersection of the logic of action (spread by the project's major figure) and the logic of the individual's affirmation that it is possible to retrace the figure of 'project leader', characterizing the production of urban nature. As Bourdin said, it is an individual who acts, who produces a project, and who is part of a network. To this Castel (2009) added that it is an individual whose status is acknowledged. This conjecture creates citizens as determined and determining subjects, thus 'project leaders' can lead (alone or in a network) a project through the project approach. Project leaders are recognized primarily by their capacity to think of the 'good' project, rather than representing the voice of their social status (as was the case in allotments), or for their municipal anchoring (in this case, of the 'engaged Parisians') that provides them with the legitimacy to act in their city'.

Thus, the removal of the public authority's responsibility for the management of spaces takes place through discourses based on sociability and sharing among citizens called to (co)manage urban nature and to proliferate its production. Nevertheless, the political, aesthetic and social contours of this process of transferring action from the public authorities to citizens are still fixed by the public authorities. It is not, therefore, a direct and free citizens' action on their living space, but it expresses a clear will of the public authority to delegate a part of its public action on nature to citizens while maintaining its control.

\section{Four Contemporary Trends in Urban Nature}

Through this analysis of the evolution that occurred in the relationship between nature, technology, and the city, it has been possible to reveal the transformations, the tensions, and the contradictions that have been part of the evolution of actors in urban greening practices and discourses in Paris. From the analysis, four main trends in urban nature emerged: urban nature gradually used as a policy instrument; urban nature slowly, yet, increasingly linked to leisure systems; urban nature that reflects the individual attitudes to city management; and urban nature in cities that is increasingly characterized by temporary, contingent, and often abandoned spaces, after they have been spectacularized.

- Nature as a political tool. As emerged from the permis de vegetaliser case study, there is a push implemented by urban citizens through 'nature projects' towards the public space: a large number of citizens decide to activate this political tool to modify the uses of public space close to where they live. Some decide to set up flower boxes to prevent cars from parking in front of their homes, and business owners' plant trees in a public space as an extension to their business space or following their personal taste.

- From primary needs to leisure events. In this context, nature is increasingly associated with other initiatives in the realm of policies for leisure and events. The goal of these policies is not so much to have nature that can satisfy primary needs or have green land that can help to combat urban heat islands (as was found in the structural injunctions set out in the hypotheses of this article). Instead, the goal is to offer leisure activities, events, and an opportunity to publicize the political goal of the local authority. These events are multiple, often temporary (such as the ' 48 hours of urban agriculture' event in 2016), and on some rare occasions, open to 'all city 
dwellers' (such as the greening workshops organized by residents for the redevelopment of Place de la Nation in 2017).

- From 'nature for all' to nature as an 'instrument for some'. These initiatives thus manifest a shift from 'nature for all' to nature which has become an 'instrument for some'; the friction between these two dimensions highlights a major controversy which characterizes the displacement of 'the power to do' from institutional actors to individuals. These individuals are not united around collective issues or demands (as was the case for allotments or even shared gardens to some extent) but project their individualities onto a nature project, and then also onto the management of public space.

- Nature as a contingent idea. Nature is being increasingly promoted by demonstrating only the most 'spectacular' moments in the long natural cycle, completely removing them from the context of the seasons, while maintaining a moralizing story about the seasons. At these events, people 'at work' try out sowing, planting, pruning, or harvesting and it does not matter what happens after these events.

In conclusion, the city of Paris is faced with an experiential, disposable, and ludic idea of nature, which repudiates the long (and often empty) time inherent in nature. This also detaches it from the world of work and places it permanently in the world of the narrative of the individual experience ('what I accomplished and how') and of Sunday leisure. Simultaneously, the microactions carried out by residents, which are often at a scale no larger than the base of a tree, are translated, and capitalized by the Municipality as contributing to a 'large urban project', using an accumulative logic. This logic means that many small areas of a few square metres if seen from the 'right height', can make up a political project on the scale of tens of hectares (the new unit of measurement for urban nature). To put it in another way,
Paris is experiencing public policies that encourage the proliferation of small events, and at the same time, 'pulverize' (Lefebvre, 1974) political action.

Furthermore, what can be turned into a 'number' (such as a public policy that only counts square metres of trees grown by city dwellers) can only be measured through its political efficiency and not its effectiveness (Jullien, 2005). This auditing of urban nature, which characterizes the relationship between the city, nature, and more recently digital devices, also highlights the dialectic between scales of objectives, actions, and actors. That is, it is a question of scale (Rey, 2014), which has consequences for the methods of analysing urban transformation, and on the way in which urban nature is acted upon.

Far from being only a Parisian question, what is described are some of the possible results of the larger process of 'democratization of democracy' (Giddens, 2002, p. 93) made through natural elements. This is a global process that goes beyond the experimentations described, and whose risks concern all urban transformation projects based on participatory demagogies.

\section{NOTES}

1. These policies have been in place since 2001 with the election of Delanoë as mayor of Paris, and they were continued with the election of Hidalgo as mayor in 2014.

2. After the end of the Second World War, allotments were of great interest to communist parties around Europe. In these spaces, they feared the spread of an individualist and liberal way of life, inconsistent with the communist political principles. Therefore, at a national communist party conference in Germany in 1948, Walter Ulbricht, the future First Secretary of the central committee of the Eastern German communist party, declared on 27 June 1948, 'the battle against the enemies of the working class leads to concerns over the organizations of gardens... As a result, garden organizations are to be placed under the supervision of institutions controlled by communist parties' (Boukharaeva and Marloie, 2015, p. 11). In France, the change in the name to family garden took place in 1952, 
with a newly incumbent right-wing government. They considered the term 'labourer' (ouvriers in French) to be too strongly linked to the communist political ideology that, along with the general interest shown by Stalin, could transform these spaces into places for the dissemination of Russian political culture. In this context, the change from 'labourer' to 'family' can be seen as an attempt to depoliticize these gardening practices.

3. In the first experiments in guerrilla-gardening seed bombs were thrown onto vacant lots, as a direct action to green the city. The aim was to help the residents of Loisaida, a Manhattan neighbourhood, to clean up several vacant lots by creating green spaces (Pasquali et al., 2008, p. 50).

4. In 1973, Liz Christy, member of the New York guerrilla-gardening group, decided to completely convert an abandoned space into urban nature: the Liz Christy Garden, not far from SoHo, was the first of the group's more permanent experiments.

5. The development of shared gardens in Paris was also possible because of funding and the interest of actors such as the Foundation of France (Fondation de France). These actors see the gardens as opportunities to develop their discourse on social connections, while remaining in contact with the questions of food and environmental processes. Research residencies on urban nature are starting to appear and 'small groups are working on these questions and are adapting, among other things, North-American practices to our urban and sociological data. They brought together, during two conferences - Lille in 1997 and Nantes in 1999 - several hundred people involved in these initiatives or wishing to develop them'. This is how the Foundation of France decided, in 1997, to support the emergence of a national network of shared gardens, subsequently called 'Le jardin dans tous ses états' (JDSE) (The garden in all its states). This project now has twelve regional sub-networks, including Grains des Jardins (Grains of Gardens), created in 2001 in the Ile-de-France region.

6. This transformation of meaning is reflected in the type of vegetation found in community gardens: inspired by the 'Third Landscape' ideology the vegetation is mainly flowers and is less and less edible and productive. According to its founder, Giles Clément (2004), Third Landscape designates the sum of spaces that, neglected or unused by humans, provide more natural wealth, in terms of biodiversity, than silvicultural and agricultural areas. An aesthetic linked to the 'wild' emerged in cities thanks also to the work of Bernadette Lizet of the Natural History Museum (1997). From the 2000s, she also wrote a significant number of books that popularized spontaneous flora in cities.

7. According to the draft legislation, which was adopted by the Senate in 2003, 'the designation "collective gardens" (jardins collectifs) refers to family gardens (jardins familiaux), reintegration gardens (jardins d'insertion), and shared gardens (jardins partagés)'.

8. Urbaphobia is not a new phenomenon: the industrial revolution saw the appearance of an entire urbaphobic ideology as a reaction to the increasing impoverishment of the working class. A large population, who had left the very poor countryside, found themselves in the big cities in wretched situations, both in terms of their work (alienation and exploitation) and their often unhealthy living conditions. A myth was thus born of the countryside and nature as a source of life (Berque et al., 2006), as opposed to the city, which was a source of criminality. England saw the birth of the first anti-urban tide (Salomon and Marchand, 2010), but the newly independent United States also based their identity essentially around rural and environmental values. They saw the source of all evils in industrial European cities: attracting migrants who quickly made themselves at home, these cities were possible revolutionary hubs. To avoid this urban development, Americans advocated a residential idyll in the suburbs, steeped in nature. This would nevertheless later create the urban sprawl of American cities (ibid.). In France, the anti-urban movement was strongly influenced by the book Paris and the French Desert (Paris et le désert français) by Jean-François Gravier. Appearing for the first time in 1947, this book was the basis of all subsequent decentralizing policies.

9. For example, the law against unsanitary housing (Lois contre le logement insalubre, 1850), Siegfried Law (Loi Siegfried, 1894), the law for the general regulation of allotments (Loi pour la réglementation générale des jardins ouvriers, 1941), and the law for the codification of the legislation on family gardens (Loi pour la codification de la législation des jardins familiaux, 1952).

10. Indeed, it is during the tenure of Bertrand Delanoë, for example, that the Charte Main Verte emerged.

11. These include 'Reinventing Paris"' (November 2014-February 2016), 'Reinventing Public Squares' (June 2015-July 2016), 'Reinventing the Seine' (March 2016-April 2017), 'Let's invent the metropolis' (October 2016-September 2017), 'The Reconquest of the Inner Ring' (2017), and 'Reinventing Paris 2: The underside of Paris' (20172018). 
12. Innovative Greening is an AMI launched by Paris City Hall, accompanied by the Paris Agency of Innovation Economic Development (Paris \& Co), and works with businesses and startups to develop 'innovative solutions' for urban greening. For this, the territorial authority proposed experimental urban plots to actors who responded to the AMI.

13. A meetup is a method of open innovation. Unlike more classic entrepreneurial methods (founded on trade secrets and patents), open innovation meetings seek to unite different actors using innovative methods (including workshops instead of direct public meetings and brainstorming phases instead of drafting preconceived documents). The goal is to get different types of actors (from city dwellers to public actors, from businesses to gardeners) to work together in a spirit of openness, seeking to develop new solutions with a common goal.

14. The Parisculteurs call for projects, seek to mobilize businesses, startups, organizations, and gardeners, to create demonstration sites of urban agriculture and greening of roofs, façades, and walls in Paris. Public land and buildings have been made available, and several multidisciplinary teams have been chosen and are now underway.

15. The Récyclerie is a Parisian bistro established in a former station in the inner ring of the city (the former railway network of Paris). With access to the largest area of unused land in Paris - the inner ring, which since its abandonment has been invaded by more or less spontaneous natural growth - the Récyclerie offers not only a restaurant but also an entire space for agricultural production, rearing of small livestock, with access to shorter production or re-employment circuits, and training linked to sustainable development. The new use of this abandoned building, located on the outskirts of Pairs, is no doubt helping to transform the face of this neighbourhood, bringing in a richer population than those who traditionally lived there.

16. The Viginature platform for self-training and sharing information on animals and plants was launched in 1989. The Sustainable Paris platform was launched in 2011, enabling the exchange of advice on greening practices, networking, and sharing of events. Collaborative experiments on urban nature platforms and citizen involvement include OASIS (Open Accessible Space Information System) in New York, with the Community Garden map (2009), as well as GardenMaps (2009-2010), and most recently the Grassroot 596 Acres map and application. This project is "promoted by a group of activists, indicating the number of vacant public plots in order to stimulate the creation of new public vegetable gardens by residents or local organizations (Bartoletti and Musarò, 2018, p. 145).

17. The digital Parisian Participatory Budgeting is a good example. This participatory initiative (promoted by Paris City Hall since 2014) enables citizens to make decisions about a part of the municipal public budget and greening is one of the themes affected by the Parisian Participatory Budgeting, among others. On the online platform, a citizen can propose his or her project, discuss it, promote it among his own community (family, professional, associative, or neighbourhood), and vote for it (the most popular projects are carried out by Paris City Hall).

\section{REFERENCES}

Aggeri, F. and Gordard, O. (2006) Les entreprises et le développement durable. Entreprises et histoire, 4(45), pp. 6-19.

Appadurai, A. and Holston, J. (1996) Cities and citizenship. Public Culture, 8(2), pp. 187-204.

Bartoletti, R. (2012) Orti e giardini collettivi: pratiche grassroots e politiche urbane. Autonomie locali e servizi sociali, 3, pp. 427-444.

Bartoletti, R. and Musarò, P. (2018) Cartographier la nature urbaine: entre politiques publiques et pratiques ordinaires, in Biase, A. de, Ottaviano, N. and Zaza, O. (eds.) Digital Polis. La ville face au numérique: enjeux d'un projet conjugué au futur. Paris: L'oeil d'or.

Bergamaschi, M. (2012) Coltivare in città. Orti e giardini condivis. Sociologia urbana e rurale, 98, pp. 60-72.

Berque, A., Bonnin, P. and Ghorra-Gobin, C. (eds.) (2006) La ville insoutenable. Paris: Belin.

Biau, V. and Tapie, G. (2009) La fabrication de la ville. Métiers et organisations. Marseille: Éditions Parenthèses.

Blanc, N. (2013) Le face-à-face citadins/nature. Multitudes, 3(54), pp. 129-139.

Boltanski, L. and Chiapello, E. (1999) Le nouvel esprit du capitalisme, Paris: Gallimard.

Boukharaeva, L.M., and Marloie, M. (2015) Family Urban Agriculture in Russia: Lessons and Prospects. Berlin: Springer.

Bourdieu, P. (1977) Outline of a Theory of Practice. Cambridge: Cambridge University Press.

Bourdin, A. (2005) La métropole des individus. La Tour-d'Aigues: Éditions de L'Aube. 
Boutinet, J.-P. (1990) Anthropologie du projet. Paris: PUF.

Bracciano, P. et al. (1995) L'arbre et les revêtements de surface. Cahier d'Arbre actuel, No. 2.

Castel, R. (2009) La montée des incertitudes. Travail, protections, statut de l'individu. Paris: Seuil.

Clément, G. (2004) Manifeste du Tiers paysage. Paris: Éditions Sujet/Objet.

Dubost, F. and Lizet, B. (2003) La nature dans la cite. Communications, 74, pp. 5-18.

Fortier, A. (2003) Les vertus du jardinage d'insertion. Communications, 74, pp. 85-102.

Gilligan, C. (1982) In A Different Voice. Cambridge, MA: Harvard University Press.

Gravier, J.-F. (1947) Paris et le désert français, Paris: Flammarion.

Guyon, F. (2008) Les jardins familiaux aujourd'hui: des espaces socialement modulés. Espaces et sociétés, 3(134), pp. 131-147.

Harvey, D. (1985 [2003]) Paris, Capital of Modernity. London: Routledge.

Hervieu, B. and Viard, J. (1997) Au bonheur des campagnes. La Tour-d'Aigues: Éditions de L'Aube.

Ingallina, P. (2001) Le projet urbain. Paris: PUF.

Jullien, F. (2005) Conférence sur l'efficacité. Paris: PUF.

Latour, B. (2002) La fabrique du droit. Paris: La Découverte.

Laugier, S. (2009) Ethics as politics of the ordinary. Multitudes, No. 2, pp. 80-88.

Lefebvre, H. (1974 [2001]) La production de l'espace. Paris: Anthropos.

Lizet, B., Wolf, A.-E. and Celecia, J. (1997) Sauvages dans la ville. Paris: Éditions du Muséum National Naturelle.
Monnier, G. and Klein, R. (eds.) (2012) Les années ZUP: architectures de la croissance. Paris: Picard.

Pasquali, M. (2008) I giardini di Manhattan: storie di guerrilla gardens. Turin: Bollati Boringhieri.

Pearson, C. (2012) La politique environnementale de Vichy. Vingtième Siècle - Revue d'Histoire, 113, pp. 41-50.

Pellegrini, S. (2012) Pieds d'arbre, trottoirs et piétons: vers une combinaison durable? Développement durable et territoires, 3(2). Available at: http:// journals.openedition.org/developpementdur able/9329.

Poulot, M. (2014) Agriculture et acteurs agricoles dans les mailles des territoires de gouvernance urbaine: nouvelle agriculture, nouveaux métiers? Espaces et sociétés, 3(158), pp. 13-30.

Rey, O. (2014) Une question de taille. Paris: Edition Stock.

Rieutort, L. (2009) Dynamiques rurales et reterritorialisation de l'agriculture. L'Information Géographique, 73(1), pp. 30-48.

Salomon, C.J. and Marchand, B. (eds.) (2010) Antiurbain: origines et conséquences de l'urbaphobie. Lausanne: Presses polytechniques et universitaires romandes.

Soulard, C.-T. and Thareau, B. (2009) Les exploitations agricoles périurbaines: diversité et logiques de développement, $5 e$ Colloque des Carrefours de l'Innovation.

Tronto, J. C. (1993) Moral Boundaries: A Political Argument for an Ethic of Care. London: Psychology Press, 1993.

Uttaro, A. (2012) Dove si coltiva la città. Community gardening e riattivazione di spazi urbani. Sociologia Urbana e Rurale, 34(98), pp. 12-27. 